\title{
THE IMPROVEMENT OF BASIC MEASUREMENT SKILLS THROUGH PAIR CHECK TYPE COOPERATIVE LEARNING MODELS
}

\author{
Windra Irdianto, Eko Edi Poerwanto, \& M. Ihwanudin \\ Universitas Negeri Malang, Jl. Semarang 5 Malang 65145 \\ e-mail: windra.irdianto.ft@um.ac.id
}

\begin{abstract}
The Improvement of Basic Measurement Skills Through Pair Check Type Cooperative Learning Models. Pair check cooperative learning is a learning model of a small group of two students who are responsible for completing academic assignments with peer guidance. This study aims to explore the effect of cooperative learning pair check models on automotive measurement subject matter. Thirty-two students were divided into two groups. One group consisting of 17 students is an experimental class, while the other group consisting of 15 students is a control class. Research data is a score of students' skills in reading the results of automotive measurements. Research data was obtained at the final evaluation of learning using a questionnaire. The results showed that the average score of the experimental class was 78.35, while the average score of the control class was 57.73 . The difference in the average score of the two groups was tested using $t$ test statistics for independent groups. The results showed that the average score of the experimental group was significantly higher than that of the control group. This shows that cooperative learning type pair check can improve students' skills in reading the results of automotive measurements.
\end{abstract}

Keywords: cooperative learning, pair check model, reading skill, automotive measurement

\begin{abstract}
Abstrak: Peningkatan Keterampilan Pengukuran Dasar Melalui Model Pembelajaran Kooperatif Tipe Pair Check. Pembelajaran kooperatif pair check merupakan model pembelajaran kelompok kecil dari dua siswa yang bertanggung jawab untuk menyelesaikan tugas akademik dengan bimbingan rekan. Penelitian ini bertujuan untuk mengeksplorasi pengaruh pembelajaran kooperatif model pair check pada materi pelajaran pengukuran otomotif. Tiga puluh dua siswa dibagi dalam dua kelompok. Satu kelas yang terdiri dari 17 siswa merupakan kelas eksperimen, sedangkan kelompok yang lain yang terdiri dari 15 siswa merupakan kelas kontrol. Data penelitian adalah skor keterampilan siswa dalam membaca hasil pengukuran otomotif. Data penelitian diperoleh pada evaluasi akhir pembelajaran menggunakan kuesioner. Hasil penelitian menunjukkan skor rata-rata kelas eksperimen adalah 78,35, sedangkan skor rata-rata kelas kontrol adalah 57,73. Perbedaan skor rata-rata dua kelompok tersebut diuji menggunakan statistik uji $t$ untuk kelompok independen. Hasil penelitian menunjukkan bahwa skor rata-rata kelompok eksperimen lebih tinggi secara signifikan dibandingkan skor rata-rata kelompok kontrol. Hal ini menunjukkan bahwa pembelajaran kooperatif tipe pair check dapat meningkatkan keterampilan siswa dalam membaca hasil pengukuran otomotif.
\end{abstract}

Kata kunci: pembelajaran kooperatif, model pair check, ketrampilan membaca, pengukuran otomotif

Automotive is one of fast growing industrial sectors (Oliver et al., 2005). The implemented technology allows humans to work on any complex product. In line with the increasingly complex automotive works, measurement requirements are also badly demanded.

The automotive world cannot be separated from a series of components that are well assembled. As consequence, measurement accuracy (Wang et al., 2016; Guerrini et al., 2018) and uniformity (Shteinhauz et al., 2004) are required. For example, auto parts can use the same factory-made parts or made in different factories in the same country or overseas. However, it must be in the same accuracy and uniformity standard..

Automotive measurement has been taught in D3 Automotive Engineering (PTO) at State University of Malang. In this course, students are expected 
to master the use of automotive equipment and measuring instruments for maintenance needs on light vehicles. Graduates are expected to work in the national-growing automotive industry.

Job opportunities in the automotive industry are still wide open. Good competency in this skill is highly demanded. Therefore, strategy for improving student competence certainly should be taken since it cannot be separated from the effective and efficient learning process. One of potential learning model is the cooperative learning model.

Cooperative learning is an small group based interactive learning method (Slavin, 2015; Desai \& Kulkarni, 2016; Gillies, 2016; Casey \& Goodyear, 2015). It is an instructional design enable students work together to achieve the learning goals. The characteristics are: (1) students work together in learning activities through working group; (2) students work together in small groups of two to five members; (3) students cooperate with each other, and apply social behavior to achieve equality or agreement in assignments or learning activities; (4) students depend on each other positively in structured activities so that students need each other to complete their general tasks or learning activities and (5) students are individually responsible or responsible for their work or learning. Cooperative learning teach students how to work together for their future works.

Pair check cooperative learning model, applies cooperative learning that requires students' independence and ability to solve problems (Rahmasari et al., 2016). This model trains students' social responsibility, cooperation, and assessment skills. The cooperative learning model of the type of pair check is a modification of the think pairs share type, where the emphasis of learning is when they are asked to check each other's answers or responses to the teacher's questions while in a partner. This study applies this model, teachers are to be motivator and facilitator of students activity.This research is conducted to see different impacts of pair check type cooperative learning model in the Automotive Measuring subject.

\section{RESEARCH METHOD}

Research subject consisted of 32 Diploma students of Measuring Class Practice divided into two groups. One group consisting of 17 students was an experimental class while another group consisting of 15 students was a control class. Experiment class was given the pair check cooperative learning model treatment, while the control class was not given any treatments. This model only used post test to compare the impact of the treatment given to the experiment class.

Pair check model learning design was applied by dividing the experiment class into groups. Each group consists of two students who were given assignment of measuring a certain working tool. Measurements were done using various measuring tools such as vernier caliper, dial caliper, micrometer, dial gauge and cylinder gauge. Measurments are done in turns. The first student measured a working tool using a given measuring tool and writes down the result. Meanwhile, the second student observed, motivated, and guided. The next turn, the first student observed, motivated, and guided, while the second student measured and wrote down the measurement result. Lastly, they discussed the result of all working tools measurement and delivered the final result to their teacher. Pair check model learning design is as shown in the Figure 1.

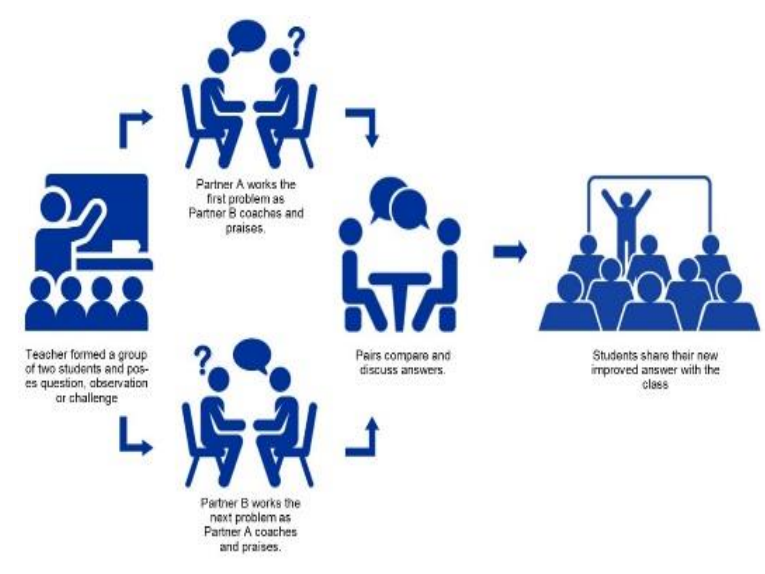

Figure 1. Pair check model learning design

Research data were students' skills in reading of measurement result collected using a questionnaire. This questionnaire included both essay and figure questions. Students were supposed to read the figures of measuring result in the questions.

\section{RESULT AND DISCUSSION}

The result includes average scores of both experiment and control classes. The scores are shown in Table 1. 
Table 1. Experiment class and control class score list.

\begin{tabular}{lcccc}
\hline \multirow{2}{*}{ No } & \multicolumn{2}{c}{ Control Class } & \multicolumn{2}{c}{ Experiment Class } \\
\cline { 2 - 5 } & Student & Score & Student & Score \\
\hline 1. & IA & 52 & AFKG & 56 \\
2. & IMR & 70 & AF & 82 \\
3. & KR & 40 & ANR & 78 \\
4. & LFA & 46 & BA & 26 \\
5. & LNA & 68 & BM & 86 \\
6. & MASP & 30 & DDS & 80 \\
7. & MAM & 68 & DA & 82 \\
8. & MAK & 76 & IMH & 84 \\
9. & MEA & 42 & KS & 78 \\
10. & MIHJP & 30 & MNA & 94 \\
11. & MYR & 88 & MS & 88 \\
12. & M & 50 & NIM & 42 \\
13. & NBI & 44 & RS & 88 \\
14. & RH & 82 & RAD & 98 \\
15. & RDP & 80 & SGA & 88 \\
16. & - & - & WPP & 88 \\
17. & - & - & YS & 94 \\
\hline
\end{tabular}

Data analysis is conducted using the scores in Table 1. It is done using IBM SPSS Statistic 20 program. Through this program, independent $t$ sample test is proceeded. The result of this examination is shown in Table 2 and 3.

Tabel 2. Statistic group

\begin{tabular}{llrrrr}
\hline Class & N & Mean & $\begin{array}{c}\text { Std. } \\
\text { Deviation }\end{array}$ & $\begin{array}{c}\text { Std. Error } \\
\text { Mean }\end{array}$ \\
\hline Skills & Control & 15 & 57.73 & 19.30 & 4.98 \\
& Experiment & 17 & 78.35 & 19.25 & 4.67 \\
\hline
\end{tabular}

Significance level in this examination is $5 \%$ or 0,05 . Table 1 show that control class has an average score of 57.73, while Experiment Class has an average score of 78,35 . It means that the class which is given pair check model cooperative learning method is better than the class without such treatment. This result can be seen from experiment class' average score which is higher than control class'. This analysis result is also supported by data in Table 3 which shows that $F=0,946$ and the significance is 0,005 , which is lower than 0,05 . It means the different average score is caused by the treatment given, pair check model cooperative learning. This result is in accordance with an earlier research (Utomo, 2016; Lestari \& Linuwih, 2012).
Tabel 3. Independent Samples Test

\begin{tabular}{|c|c|c|c|}
\hline & & \multicolumn{2}{|c|}{ Skills } \\
\hline & & $\begin{array}{c}\text { Equal } \\
\text { variances } \\
\text { assumed }\end{array}$ & $\begin{array}{c}\text { Equal } \\
\text { variances } \\
\text { not assumed }\end{array}$ \\
\hline \multirow{2}{*}{$\begin{array}{l}\text { Levene's } \\
\text { Test for } \\
\text { Equality } \\
\text { of Vari- } \\
\text { ances }\end{array}$} & $F$ & .946 & \\
\hline & Sig. & .339 & \\
\hline \multirow{7}{*}{$\begin{array}{l}t \text {-test for } \\
\text { Equality } \\
\text { of Means }\end{array}$} & $t$ & -3.020 & -3.019 \\
\hline & $\mathrm{df}$ & 30 & 29.486 \\
\hline & Sig. (2-tailed) & .005 & .005 \\
\hline & Mean Difference & -20.620 & -20.620 \\
\hline & Std. Error Difference & 6.828 & 6.829 \\
\hline & $\begin{array}{l}\text { 95\% Con- Lower } \\
\text { fidence In- }\end{array}$ & -34.564 & -34.576 \\
\hline & $\begin{array}{l}\text { terval of } \\
\text { the Differ- Upper } \\
\text { ence }\end{array}$ & -6.675 & -6.663 \\
\hline
\end{tabular}

\section{CONCLUSION}

Through pair check model cooperative learning, students experience learning process in groups of two. Each group is given working tools to be measured by a member of the group, and the result is to be examined by the pair. Things that should be checked are standard operating procedure (SOP) and measuring result. pair check model cooperative learning impacts on the increasing of automotive measuring skills.

The research result demonstrates that average scores of the class with pair check learning model is higher than the other class which receives no treatment. Students in the experiment class are more interactive in the learning process. They give suggestion to each other in measuring and using measuring tools, while Control Class students do not do such things.

\section{ACKNOWLEDGEMENTS}

This research is supported by Mechanical Engineering (ME) Department, Faculty of Engineering, Universitas Negeri Malang. We would like to thank the department for the access to the Metrology Laboratory along with the technician. Our gratitude is also addressed to fellow lecturers who have shared their suggestions, knowledge, and proficiency for the sake of this research. 


\section{REFERENCES}

Casey, A. \& Goodyear, V.A. 2015. Can cooperative learning achieve the four learning outcomes of physical education? A review of literature. Quest, 67(1): 56-72.

Desai, T.S. \& Kulkarni, P.P. 2016. 'Cooperative Learning' Tool for Optimizing Outcomes of Engineering Education. Journal of Engineering Education Transformations. Special Issue of National Conference NCIEME 2016 Organised by Rajarambapu Institute of Technology and Walchand College, Sangli ISSN 2394 - 1707.

Gillies, R.M. 2016. Cooperative learning: Review of research and practice. Australian Journal of Teacher Education, 41(3): 39-54.

Guerrini, G., Landi, E., Peiffer, K., \& Fortunato, A. 2018. Dry grinding of gears for sustainable automotive transmission production. Journal of Cleaner Production, 176: 76-88.

Lestari, R. \& Linuwih, S. 2012. Penerapan Model Pembelajaran Kooperatif Tipe Pair Checks Pemecahan Masalah Untuk Meningkatkan Social Skill Siswa. Jurnal Pendidikan Fisika Indonesia, 8: 190-194.

Oliver, N., Holweg, M., \& Luo, J. 2005. The past, present and future of China's automotive industry: a value chain perspective. International Journal Technological Learning, Innovation and Development, 2 (1-2): 76-118.
Rahmasari, L.L., Wahyudi, \& Susiani, T.S. 2016. Penerapan Model Kooperatif Tipe Pair Check dengan Media Konkret dalam Peningkatan Pembelajaran Matematika tentang Pecahan Pada Siswa Kelas IV SD Negeri Jlegiwinangun Tahun Ajaran 2015/2016. Kalam Cendekia, 4 (6.1): 686-691.

Shteinhauz, G.D. \& Luk, Y.W. 2004. , inventors; Goodyear Tire, Rubber Co, assignee. Cross-correlation method for identification and removal of machine contribution from tire uniformity measurements. United States patent, US 6,705,156. 2004 Mar 16.

Slavin, R.E. 2015. Cooperative learning in elementary schools. International Journal of Primary, Elementary and Early Years Education, 43(1): 514.

Utomo, E.S. 2016. Pengaruh Model Pembelajaran Kooperatif Tipe Jigsaw Terhadap Hasil Belajar Siswa. Prosiding Seminar Nasional Matematika dan Pendidikan Matematika Universitas Negeri Yogyakarta 2016: 475-480.

Wang, H., Zhou, J., Zhao, T., \& Tao, Y. 2016. Springback compensation of automotive panel based on three-dimensional scanning and reverse engineering. The International Journal of Advanced Manufacturing Technology, 85 (5-8):1187-1193. 